Biografistyka Pedagogiczna

Rok 3 (2018) nr 1

ISSN 2543-6112; e-ISSN 2543-7399

DOI: 10.36578/BP.2018.03.21

Ryszard Skrzyniarz*

\title{
Dokumenty źródłem analiz i badań biograficznych w pedagogice
}

\section{Documents As a Source of Analysis and Biographical Research in Pedagogy}

Od pewnego czasu nurtuje mnie myśl, a raczej pomysł wynikający z potrzeb, aby powstała praca dotycząca metodologii badań biograficznych w pedagogice, jak jest to $\mathrm{w}$ socjologii ${ }^{1}$, która wypracowała własne metody badań biograficznych. To wcale nie znaczy, że w pedagogice ich w ogóle nie $\mathrm{ma}^{2}$, jednak warto się zastanowić nad powstaniem takiego podręcznika. Pisząc ten artykuł, mam nadzieję, że wzbudzi on polemikę wśród badaczy biografii. Chodzi mi o wywołanie dyskusji nad metodami badań biograficznych w pedagogice.

Na wstępie swoich rozważań wyjaśnię, dlaczego zabrałem się za napisanie tego artykułu? Po pierwsze, moi studenci ciągle mnie pytają o literaturę, która byłaby pomocna w ich pracach badawczych, a po drugie,

* Ryszard Skrzyniarz - dr hab. prof. Katolickiego Uniwersytetu Lubelskiego Jana Pawła II, kierownik Katedry Biografistyki Pedagogicznej w Instytucie Pedagogiki, skrzyniarz@kul.pl.

1 Metoda biograficzna $w$ socjologii, red. J. Włodarek, M. Ziółkowski, Warszawa-Poznań 199o; Metoda biograficzna w socjologii. Antologia tekstów, red. K. Kaźmierska, Kraków 2012; Metoda biograficzna w socjologii. Antologia tekstów, red. K. Kaźmierska, Kraków 2012.

2 Na przykład: D. Lalak, A. Ostaszewska, Źródła do badań biograficznych. Listy - dzienniki - pamiętniki-blogi-materiały wizualne, Warszawa 2016 oraz artykuły w: Badania biografii - źródła, metody, konteksty, red. R. Skrzyniarz, E. Krzewska, W. Zgłobicka-Gierut, t. 5, Lublin 2014; Przedmiot, źródła i metody badań $w$ biografii, red. R. Skrzyniarz, L. Dziaczkowska, D. Opozda, t. 9, Lublin 2016, a także publikacje w serii „Biografia i badanie biografii” wydawanej przez prof. Elżbietę Dubas z Uniwersytetu Łódzkiego. 
coraz częściej spotykam się wśród badaczy z niezrozumieniem terminu „dokument". Po trzecie, zauważyłem, że niektórzy badacze boją się korzystać z tak zwanych dokumentów historycznych (źródeł ${ }^{3}$ archiwalnych). Nie dziwię się im, ponieważ trzeba mieć odpowiednie przygotowanie do interpretacji dokumentów archiwalnych wytworzonych w minionych epokach, a także umiejętność ich poszukiwania i odpowiedniej selekcji oraz krytyki.

Wchodzimy tu bowiem w obszar niełatwej metodologii historii, która również dotyczy zachowanych śladów przeszłości. Istnieją różne definicje tzw. źródła historycznego ${ }^{5}$. Obecnie bardzo powszechną, ponieważ łączącą się z coraz szerszym pojęciem przedmiotu badań oraz z ujęciem interdyscyplinarnym, jest ta, uznająca za źródło każdą rzecz, którą poddajemy obserwacji, aby zdobyć dane do poznania naszego przedmiotu badań.

Tak więc źródła dzielą się na pisane oraz wszystkie pozostałe (w tym np. archeologiczne, etnograficzne, ikonograficzne, językoznawcze i inne; materialne i niematerialne). Pisane, uważane za klasyczne dla historii, tworzone są przez dwie grupy - aktowe i opisowe. Te ostatnie z kolei obejmują historiograficzne (np. roczniki, kroniki, hagiografie, biografie), pamiętnikarskie (pamiętniki, roczniki, relacje), publicystyczne oraz korespondencyjne ${ }^{6}$.

W tym miejscu chciałbym tylko wspomnieć, że na badania historyczne

3 B. Kožuh, Źródła w interpretacji badań biograficznych, Częstochowa 2002.

4 R. Skrzyniarz, Zmagania $z$ archiwami $w$ kontekście badań biograficznych, „Roczniki Pedagogiczne”, 8 (44) $2016 \mathrm{nr}$ 1, s. 63-77.

5 Np. „Źródło historyczne jest to świadectwo przeszłości, przy pomocy którego możemy [...] poznać jakieś fakty z tejże przeszłości.", A. Swieżawski, Warsztat naukowy historyka. Wstęp do badań historycznych, Częstochowa 2001, s. 116, tam też i inne definicje źródła historycznego, s. 116-118; B. Miśkiewicz, Wstęp do badań historycznych, Warszawa 1973, s. 113-116; J. Szymański, Nauki pomocnicze historii, Warszawa 2004, s. 28-69.

6 A. Swieżawski, Warsztat naukowy historyka, s. 121-135.

7 Krytyce źródeł historycznych w badaniach biograficznych chciałbym poświęcić w przyszłości oddzielny artykuł. składają się trzy etapy metodologii: heurystyka, krytyka źródeł oraz opracowanie historiograficzne ${ }^{7}$. Krytyka zewnętrzna zwana niższą lub erudycyjną ma na celu stwierdzenie autentyczności źródła i wykorzystuje badania czasu, miejsca oraz autorstwa. Dla każdego badacza zdecydowanie bardziej potrzebna, ponieważ nieustannie używana, jest krytyka wewnętrzna źródła (wyższa, hermeneutyka), polegająca na interpretacji i ocenie wiarygodności zawartych w nim informacji. Heurystyka i krytyka pozostają te same, choć końcowy efekt - opracowanie historiogra- 
fii lub biografii jest niekiedy inny ze względu na ostateczne cele, np. pedagogiczne. Natomiast wykorzystujące właściwie ten sam proces badawczy. Tutaj kluczowym zagadnieniem jest osoba autora (m.in. jego pochodzenie, poglądy, wykształcenie, cele, źródła informacji, cenzura, rodzaje zachęty, przynależność do danej grupy, np. koterii). Bardzo dobrym, choć nie zawsze możliwym zabiegiem jest także zastosowanie konfrontacji z faktami znanymi z innych źródeł ${ }^{8}$.

W poniższych rozważaniach zajmę się podaniem definicji dokumentu i rodzajami dokumentów, następnie przedstawię pokrótce rolę i znaczenie dokumentów w procesie badawczym nad biografią pedagogiczną.

\section{Dokument i rodzaje dokumentów}

Jedną z metod badawczych w biografistyce pedagogicznej jest analiza wszelkiego rodzaju dokumentów wytworzonych przez osobę biografowaną lub środowisko z nią związane. Termin dokument nie jest łatwy do zdefiniowania, zwłaszcza na gruncie pedagogiki, w której tym mianem określa się przede wszystkim współczesną dokumentację wytworzoną w procesie edukacji ${ }^{9}$.

W literaturze spotykamy też określenie, że dokumentem jest „każdy przedmiot materialny będący świadectwem jakiegoś faktu, zjawiska lub myśli ludzkiej”10, zaś Mieczysław Łobocki dodaje: „a nade wszystko wszelki ślad pozostawiony przez człowieka na materialnym przedmiocie" ${ }^{\prime 11}$. Natomiast według Alberta Wojciecha Maszke dokumentami są: „wszelkie przedmioty będące wynikiem celowej działalności instytucji oświatowo-wychowawczych i obejmujących zarówno dokumenty pisane, jak i wszystkie wytwory dzieci, młodzieży i dorosłych i stanowiące określone źródło informacji"12. Józef Sztumski pisze o dwóch znaczeniach słowa dokument: 1) jako występujący w dowolnej postaci dowód istnienia określonych faktów i wydarzeń społecznych; 2) jako pisemne świadectwo określonych faktów i wydarzeń społecznych ${ }^{13}$.

Dla pedagoga, badacza biografii, dokument to nie tylko pismo

8 A Swieżawski, Warsztat naukowy historyka, s. 156169; B. Miśkiewicz, Wstęp do badań historycznych, S. $175-181$.

9 M. Łobocki, Metody i techniki badań pedagogicznych, Kraków 2013, s. 214-215.

10 Dokument, w: Nowa encyklopedia powszechna PWN, t. 2, Warszawa 1995, s. 96.

11 M. Łobocki, Metody i techniki badań pedagogicznych, s. 213.

12 A. W. Maszke, Metodologiczne podstawy badań pedagogicznych, Rzeszów 2003, s. 176.

13 J. Sztumski, Wstęp do metod i technik badań spotecznych, Warszawa 1984, s. 100. 
urzędowe i potwierdzone pieczęcią, ale przede wszystkim każda rzecz, która będzie przedmiotem analiz podejmowanych w celu ustalenia biografii pedagogicznej, edukacyjnej czy wychowawczej.

Spróbujmy pokusić się o zdefiniowanie, czym jest dokument w badaniach biograficznych? Według Władysława Piotra Zaczyńskiego „dokumentem jest każda rzecz mogąca stanowić źródło informacji, na podstawie której można wydawać uzasadnione sądy o przedmiotach, ludziach i procesach"14. Zatem są to dokumenty pisane, elektroniczne (obrazowe, dźwiękowe), a także przedmioty, którymi osoba biografowana posługiwała się lub otaczała, mogą to być nawet miejsca zamieszkania, edukacji czy pracy. Tak szerokie ujęcie definicji pozwala na rozszerzenie interpretacji, czym jest dokument. To nie tylko źródła pisane, jak chcieliby historycy, ale także wszelkiego rodzaju dokumenty elektroniczne wytworzone współcześnie, z których chętnie korzystają pedagodzy, psycholodzy i socjolodzy, oraz dokumentacja ikonograficzna i dźwiękowa, a także przedmioty codziennego użytku. Ta definicja pozwala objąć mianem dokumentu wszystkie te źródła, które umożliwiają opowiedzenie biografii całościowej lub tylko cząstkowej (wybranej).

$\mathrm{Na}$ użytek badań biograficznych wypracowałem własną definicję dokumentu, potrzebną do skonstruowania biografii pedagogicznej. A mianowicie - dokumentem są: wszystkie pisemne, obrazowe, dźwiękowe, elektroniczne informacje oraz przedmioty stanowiące źródło wiedzy o człowieku, na podstawie których można mówić/pisać/stawiać hipotezy dotyczące jego biografii i zachodzących w niej procesów edukacyjnych i wychowawczych oraz wpływów pedagogicznych na osobę biografowaną, a także jej wpływ na inne osoby czy środowisko życia.

Według Zaczyńskiego dokumenty dzielimy ze względu na: 1) formę: pisane, cyfrowe i obrazowe; 2) pochodzenie: zastane i intencjonalnie tworzone; 3) twórcę: urzędowe, oficjalne, wytwory własne nauczycieli i uczniów ${ }^{15}$.

Dokumenty można dzielić różnie, a o ich podziale powinno/może decydować

14 W. P.Zaczyński, Poradnik autora prac seminaryjnych, dyplomowych i magisterskich, Warszawa 1995, s. 15.

15 W. P. Zaczyński, Zasady badań pedagogicznych, w: Pedagogika ogólna i subdyscypliny, t. 2, red.

L. Turos, Siedlce 1997, s. 127. określenie założenia, do jakich celów badawczych zostaną one wykorzystane. W tym przypadku chodzi o ich wykorzystanie do badań biograficznych w pedagogice, gdzie oprócz bio- 
grafii badacz chce uzyskać informacje na temat pedagogicznej roli osoby biografowanej bez względu na pozytywny czy negatywny wynik końcowy.

Aby uprościć różnorodne podziały, pozwoliłem sobie na przedstawienie szczegółowej klasyfikacji dokumentów w trzech grupach. Pierwszą grupę stanowią dokumenty źródłowe, drugą - dokumenty audiowizualne, trzecią zaś przedmioty do badań biograficznych.

1. Dokumenty klasyczne (źródłowe) - pisane (historyczne, osobiste):

- dokumenty poświadczające: dowód (książeczka, karta plastikowa), odpisy (akt urodzenia, chrztu, zgonu), paszport, legitymacje służbowe, szkolne, prawo jazdy, legitymacje odznaczeń, przepustki, pozwolenia, karty biblioteczne, legitymacje (np. Pck, harcerskie, honorowego krwiodawcy), identyfikatory;

- dokumenty dotyczące okresu edukacji (szkoły i studia) ${ }^{16}$ : zeszyty, kroniki klasowe i szkolne ${ }^{17}$, dziennik ocen, dzienniczek ucznia, prace szkolne (rysunki ${ }^{18}$, pamiętniki), świadectwa szkolne, indeks, dyplomy studiów, wyróżnienia, dyplomy i certyfikaty (kursy, osiągnięte wyniki w sporcie, ...), nagrody, świadectwo złożenia egzaminu (czeladniczego, mistrzowskiego), dyplomy stopni i tytułów naukowych (magistra, doktora, habilitacji, uzyskania tytułu profesora);

- dokumenty ustawowe: ustawy, rozporządzenia, urzędowe sprawozdania, raporty;

- dokumenty urzędowe (dla i od urzędów oraz instytucji publicznych ${ }^{19}$ : podania, pisma kierowane do osób i instytucji, zawiadomienia, listy urzędowe, odpowiedzi, podziękowania, zawiadomienia/powiadomienia;

16 I. Nadolnik, Fakty, ludzie, wydarzenia. Dokumenty szkolne jako źródło wiedzy do poznania działalności dydaktyczno-wychowawczej dyrektorów i nauczycieli, w: Przedmiot, źródła i metody badań w biografii, red. R. Skrzyniarz, L. Dziaczkowska, D. Opozda, t. 9, Lublin 2016, s. 291-306.

17 P. Gołdyn, Wattki biograficzne nauczycieli w kronikach szkolnych. Przykład Wielkopolski wschodniej, w: Przedmiot, źródła i metody badań $w$ biografii, red. R. Skrzyniarz, L. Dziaczkowska, D. Opozda, t. 9, Lublin 2016, s. 309-322.

18 B. Kostrubiec-Wojtachnio, Obca wśród swoich. Migracja wewnątrzosobowa nastolatki i jej rozwój emocjonalny wobec uzależnienia bliskiej rodziny udokumentowane rysunkiem projekcyjnym, w: Obcy/inny wśród swoich. Wychowawczy wymiar biografii, red. R. Skrzyniarz, t. 10, Lublin 2017, s. $153-168$.

19 K. Sabat, Prośba o ułaskawienie źródłem do biografii Żołnierzy Wyklętych, „Biografistyka Pedagogiczna", 1 (2016) nr 1, s. 275-291. 
20 M. Kobierecki, Korespondencja króla Stanisława Augusta $z$ Antonim Dziekońskim konsyliarzem Rady Nieustającej w 1783 r. jako element budowy biografii, w: Badania biografii - źródła, metody, konteksty, red. R. Skrzyniarz, E. Krzewska, W. Zgłobicka-Gierut, t. 5, Lublin 2014, s. 231-247; J. Kolbuszewska, Listy prywatne jako źródło do badań nad przeszłością. Kilka uwag o potencjale informacyjnym, ograniczeniach, sposobach wykorzystania, w: Przedmiot, źródła i metody badań w biografii, red. R. Skrzyniarz, L. Dziaczkowska, D. Opozda, t. 9, Lublin 2016, S, 253-264; A. Chrobot, Listy poetyckie Jerzego Sabinusa jako źródło informacji biograficznych, w: tamże, s. 265-277; M. Gajderowicz, Listy Joanny Beretty Molli i Piotra Molli jako źródło biograficzne, „Biografistyka Pedagogiczna", 1 (2016) nr 1, s. 383-394; K. Wołk, Listy Zygmunta Kukulskiego z okresu szkockiego źródłem badań biograficznych, tamże, s. 395-405.

21 D. Grabowska, Autorytet nauczyciela w źródłach autobiograficznych XIX wieku, w: Biografie nauczycieli i pedagogów. Idee i programy, red. R. Skrzyniarz, G. Bujak, K. Kołtuniewicz, t. 2, Lublin 2013, s. 47-59; U. Chęcińska, Pedagogia Joanny Kulmowej w kontekście autobiograficznym, tamże, s. 217-228; E. Bender, Autobiografia wobec historycznego tabu. Arturo Barea i hiszpańska wojna domowa 1936 roku, w: Biografia w literaturze i sztuce, red. R. Skrzyniarz, E. Krzewska, E. Kuryluk, t. 4, Lublin 2014, s. 17-28; S. Michalska, Autobiografia w samotności. Samotność jako czynnik twórczy, w: tamże, s. 29-37; M. Parzych, Autobiograficzne porachunki. „Mercedes-Benz" Pawła Huellego jako niepokojąco osobista powieść z kluczem, w: tamże, s. 39-50; U. Tabor, Niedorosłe (auto)biografie - narracje osobiste $w$ perspektywie dziecięcej, w: tamże, s. 53-67; T. Zawojska, Żywot człowieka uczciwego. Wychowanie domowe podstawa etosu polskiej inteligencji w świetle autobiografii Stanisława Gieysztora „Moja Warszawa”,
- dokumenty epistolograficzne: listy ${ }^{20}$, kartki świąteczne i okolicznościowe, grypsy (obozowe, więzienne, ...);

- dokumenty intymne/wewnętrzne: autobiografie ${ }^{21}$, pamiętniki ${ }^{22}$, wspomnienia ${ }^{23}$, narracje ${ }^{24}$, zapiski, dzienniki (własne i cudze) ${ }^{25}$, kalendarze z wpisami;

- dokumenty okolicznościowe: dyplomy, wyróżnienia, podziękowania, mowy okolicznościowe (pogrzeb, ślub, jubileusz, ...), przemówienia, zaproszenia (ślubne, na koncerty, wystawy, inauguracje, wręczenie dyplomu itp.), informatory;

- dokumenty dotyczące twórczości: naukowej, literackiej, artystycznej, filmowej, malarskiej itp. (umowy, recenzje, polemiki, ...);

- dokumenty medyczne: karty zdrowia, prześwietlenia, dokumenty szpitalne, wyniki badań, zgromadzona różnego rodzaju dokumentacja medyczna;

- dokumenty sądowe: spadki, zapisy, testamenty, akta notarialne ${ }^{26}$, księgi wieczyste (wypisy), sprawy sądowe;

- dokumenty bankowe: umowy, kredyty, karty bankomatowe, wyciągi bankowe, rachunki bankowe, telefoniczne, lokaty;

- dokumenty finansowe: skarbowe, płacowe, zus, funduszy emerytalnych, ubezpieczycieli; 
tamże, s. 81-95; C. Michoński, Ucieczka od cywilizacji. Wszystko za życie Jona Krakauera jako przykład auto/biografii pogranicza, w: Obcy/inny wśród swoich. Wychowawczy wymiar biografii, red. R. Skrzyniarz, t. 10, Lublin 2017, s. 33-46; K. Burzyńska-Kaniewska, Na pograniczu słów. Zaburzenia psychosomatyczne w autobiografii Marie Cardinal, w: tamże, s. 73-81; E. J. Konieczna, Poszukiwanie sensu życia. Terapeutyczny wymiar pisarstwa autobiograficznego, w: tamże, s. 169-183.

22 M. R. Górniak, Kształtowanie się powojennych społeczności regionalnych na Ziemiach Odzyskanych w świetle pamiętników, relacji i wspomnień osadników z terenu Ziemi Głogowskiej, „Biografistyka Pedagogiczna”, 1 (2016) nr 1, s. 193-216.

23 M. Gajderowicz, Obraz matki w twórczości i wspomnieniach więźniów Majdanka, w: Wzory i wzorce osobowe w biografistyce pedagogicznej, red. R. Skrzyniarz, M. Gajderowicz, T. Wach, t. 3, Lublin 2013, s. 235-249; M. Żmudziak, Stanisław Fita (1932-2011) świadectwo, wspomnienie, echa działalności naukowej, w: W służbie nauki, wychowania i wartości. Szkice biograficzne o lubelskim środowisku naukowym, red. R. Skrzyniarz, M. Łobacz, B. Borowska, t. 8, Lublin 2015, s. 297-306; J. Jabłońska, „Uniwersytet Marii Curie-Skłodowskiej i ja" - znaczenie Lublina w życiu studentki z przełomu lat pięćdziesiątych i sześćdziesiątych XX wieku, w: tamże, s. 517-533; K. Kusiak, Rekonstrukcja doświadczeń dotyczących własnych nauczycieli $w$ budowaniu tożsamości zawodowej nauczyciela, w: Przedmiot, źródła i metody badań w biografii, red. R. Skrzyniarz, L. Dziaczkowska, D. Opozda, t. 9, Lublin 2016, s. 183-196.

24 D. Opozda, Pedagogiczna analiza doświadczeń rodzinnych $w$ narracjach, w: Przedmiot, źródła i metody badań w biografii, red. R. Skrzyniarz, L. Dziaczkowska, D. Opozda, t. 9, Lublin 2016, s. 105-117; E. Krzewska, R. Skrzyniarz, „Wokół Uniwersytetu" - narracje emerytowanych pracowników uczelni o Katolickim Uniwersytecie Lubelskim. Wstęp do badań, „Biografistyka Pedagogiczna”, 1 (2016) nr 1, s. 291-302.

25 R. Kramar, W przededniu katastrofy: nastroje społeczne na Ukrainie sowieckiej w latach dwudziestych XX wieku (na materiałach „nowego folkloru” $z$ „Dziennikow” Serhija Jefremowa), w: Biografia w edukacji etnoregionalnej, red. R. Skrzyniarz, E. Kuryluk, B. Drozd, t. 6, Lublin 2014, s. 175-192; M. Łobacz, „Dzienniczek” świętej siostry Faustyny Kowalskiej - źródłem poznania wartości słabego człowieka, w: Przedmiot, źródła i metody badań w biografii, red. R. Skrzyniarz, L. Dziaczkowska, D. Opozda, t. 9, Lublin 2016, s. 367-389; R. Skrzyniarz, Obraz siebie siostry Faustyny Kowalskiej na podstawie „Dzienniczka", w: Obcy/inny wśród swoich. Wychowawczy wymiar biografii, red. R. Skrzyniarz, t. 10, Lublin 2017, s. 47-72; D. Sula, Na granicy życia i śmierci. Doświadczenia obozowe w dzienniku Abrahama Kajzera, „Biografistyka Pedagogiczna”, 1 (2016) nr 1, s. 127-144.

26 S. Kowalska, Akta notariuszy kaliskich z okresu międzywojennego - źródłem wiedzy do biografii społeczności, w: Badania biografii - źródła, metody, konteksty, red. R. Skrzyniarz, E. Krzewska, W. Zgłobicka-Gierut, t. 5, Lublin 2014, s. 249-262. 
- dokumenty statystyczne i liczbowe: wykazy, zestawienia, tabele, roczniki statystyczne i opracowania Głównego Urzędu Statystycznego, wszelkiego rodzaju typologia;

- dokumenty zakładu pracy: prywatnej firmy (jako właściciel), dokumenty pracowników ${ }^{27}$, dokumentacja techniczna;

- dokumenty fundacyjne i dobroczynne: fundacje, stowarzyszenia, zapisy, stypendia;

- dokumenty religijne: kazania, rekolekcje, rady wychowawcze, świadectwa, dzienniki, „wyznania duszy”;

- dokumenty wywołane: spisane wywiady (transkrypcja wywiadów) ${ }^{28}$, sprawozdania ze spotkań, wystąpień, dyskusje;

27 A. Chamera-Nowak, Centralny Urzad Wydawnictw, Przemystu Graficznego i Księgarstwa jako epizod $w$ biografii Karola Kuryluka, w: Biografia w literaturze i sztuce, red. R. Skrzyniarz, E. Krzewska, E. Kuryluk, t. 4, Lublin 2014, s. 225-240.

28 D. Baraniewicz, Biografia szkolna uczniów z (nie) pełnosprawnościq złożona, w: Przedmiot, źródła $i$ metody badań $w$ biografii, red. R. Skrzyniarz, L. Dziaczkowska, D. Opozda, t. 9, Lublin 2016, s. 119131; R. Skrzyniarz, „Czas i odległość, jakie znamy nie istnieja” - doświadczenia śmierci w biografii „Biografistyka Pedagogiczna", 1 (2016) nr 1, s. 177-192.

29 A. Chrobot, Epitafium jako jedna z krótszych form zapisu biograficznego, w: Badania biografii - źródła, metody, konteksty, red. R. Skrzyniarz, E. Krzewska, W. Zgłobicka-Gierut, t. 5, Lublin 2014, s. 119-132.

30 E. Krzewska, Mowy pogrzebowe jako opowieść o życiu i działalności Tekli $z$ Wodzickich Małachowskiej, w: tamże, s. 133-147.

31 Ł. Kosiński, Hagiografia jako typ biografii na podstawie wczesnośredniowiecznych żywotów świętych irlandzkich $z$ terenu Ulsteru (VII-VIII wiek), w: Przedmiot, źródła i metody badań $w$ biografii, red. R. Skrzyniarz, L. Dziaczkowska, D. Opozda, t. 9, Lublin 2016, s. 405-414.

32 A. Jabłońska, Biografistyka zaklęta w legendzie. Podania jako element obrazu lokalnych społeczności i ich regionu, w: Biografia w literaturze i sztuce, red. R. Skrzyniarz, E. Krzewska, E. Kuryluk, t. 4, Lublin 2014, s. 133-145.
- dokumenty reklamowe: wizytówki, bileciki, foldery, reklamy;

- dokumenty terenowe: notatka terenowa jako technika rejestracji danych;

- dokumenty funeralne: nekrologi, inskrypcje, epitafia nagrobne ${ }^{29}$, kazania/mowy pogrzebowe ${ }^{30}$;

- dokumenty wtórne - powstałe na bazie dokumentów pierwotnych, które zaginęły lub zostały odtworzone $\mathrm{w}$ oparciu o inną dokumentację, która była źródłową (np. świadectw szkolne, wyciągi $\mathrm{z}$ akt metrykalnych).

Oddzielną grupę dokumentów stanowią:

- druki (wszelkiego rodzaju dedykacje, wpisy, biografie, słowa o autorze, ...);

- hagiografia ${ }^{31}$, legendy ${ }^{32}$, podania, baśnie;

- pieczęcie: królewskie, urzędowe, pieczątki prywatne, exlibrisy;

- mapy. 
Chociaż pieczęcie nie są same w sobie dokumentem, stanową nieodłączną część dokumentu historycznego i współczesnego. O ile współczesne dokumenty poświadczają autentyczność dokumentu, o tyle dokumenty historyczne zawierają często pieczęcie swoich wystawców, a więc herb, dewizę czy inne elementy identyfikujące go z rodem czy pełnioną funkcją (starosta, wojewoda, biskup) Mapa jest również specyficznym rodzajem dokumentu, gdyż może zawierać notatki czy trasy peregrynacji, przez co stają się często jedynym dokumentem z podróży. Według mnie istotne znaczenie maja dokumenty hagiograficzne i nie chodzi tu o starożytną czy średniowieczną hagiografię, ale współczesną, która powstaje po śmierci jakiejś osoby na bazie wspomnień czy wywiadów. Do tej grupy dokumentów warto dołączyć legendy, podania i baśnie, które narosły na przestrzeni dziejów i są najczęściej związane z miejscem oraz osobami, których dotyczą, a źródłowo nie są już, albo nigdy nie były uchwytne. Natomiast w różnego rodzaju drukach znajdziemy dedykacje dla władców, papieży, biskupów, możnowładców, a przede wszystkich opiekunów i sponsorów wydania. Znajdą się tam też rękopiśmienne wpisy (czasami bardzo zaskakujące w swojej treści), biografie autora lub innych osób z nim lub publikacją związanych.

Ze względu na miejsce przechowywania możemy mówić o dokumentach wytworzonych w ciągu/nurcie życia znajdujące się w archiwach: państwowych ${ }^{33}$, kościelnych (parafialne, diecezjalne, zakonne), uniwersyteckich, zakładowych, prywatnych ${ }^{34}$, bibliotekach, zbiorach specjalnych.

Poszukiwania źródeł do badań biograficznych należy rozpocząć w domowych szufladach, pudełkach czy szkatułkach, aby następnie udać się do archiwów, bibliotek, muzeów, zbiorów prywatnych ${ }^{35}$. Pomocne w poszukiwaniu dokumentów biograficznych mogą stać się także biblioteki, w których mogą znajdować się spuścizny lub przekazane księgozbiory.

„Badania biograficzne nie istnieją bez źródeł historycznych, są one podstawą każdej narracji biograficznej" - tak napisała Anita Całek ${ }^{36}$,

33 P. Jędrzejewski, Akta krakowskich Komisji Porządkowych Cywilno-Wojskowych jako źródło do biografii urzędniczych i zbiorowych, w: Przedmiot, źródła i metody badań w biografii, red. R. Skrzyniarz, L. Dziaczkowska, D. Opozda, t. 9, Lublin 2016, S. 241-251.

34 P. Wrona, Biograf bez archiwów. Nie-dokumentowe źródła historyczne $w$ warsztacie biografistyki historycznej, w: Przedmiot, źródła i metody badań w biografii, red. R. Skrzyniarz, L. Dziaczkowska, D. Opozda, t. 9, Lublin 2016, s. 279-290.

35 R. Skrzyniarz, Zmagania z archiwami, s. 65 i nn.

36 A. Całek, Biografia naukowa: od koncepcji do narracji. Interdyscyplinarność, teorie, metody badawcze, Kraków 2013, s. 185. 
a Danuta Lalak i Aneta Ostaszewska dodają: „biografia udokumentowana źródłowo jest ścieżką do zrozumienia istoty i sensu życia" ${ }^{37}$. W całej rozciągłości zgadzam się z powyższymi wypowiedziami. Żaden badacz w trakcie zbierania materiałów do biografii, a szczególnie biografii całościowej, nie powinien pomijać źródeł historycznych, dokumentów wytworzonych w przeciągu życia osoby biografowanej. Utarło się, że biografia może być współczesna, to jest najczęściej dwudziestowieczna, w najgorszym wypadku dziewiętnastowieczna, lub też biografia współczesna, cząstkowa. Badacz biografii pedagogicznej nie powinien uciekać przed zgłębianiem biografii ze wszystkich minionych epok, nawet ze starożytności, w której biografie również mogą i mają walor wychowawczy czy edukacyjny ${ }^{38}$. Cenne będą również biografie z okresu średniowiecza i epok bardziej nam współczesnych ${ }^{39}$. W tego typu biografiach badacz z konieczności musi sięgnąć do źródeł zachowanych, a znajdujących się w archiwach i bibliotekach. Biografista winien zachować się jak detektyw w poszukiwaniu źródeł

37 D. Lalak, A. Ostaszewska, Źródła do badań biograficznych, s. 16.

38 B. Proc, Żywot Artakserkses w twórczości Plutarcha $z$ Cheronei, w: Biografia w literaturze i sztuce, red. R. Skrzyniarz, E. Krzewska, E. Kuryluk, t. 4, Lublin 2014, s. 123-132; T. Krynicka, „Poemat dziękczynny” Paulina z Pelli - opowieść o codzienności poetyBożego tułacza, w: Przedmiot, źródła i metody badań $w$ biografii, red. R. Skrzyniarz, L. Dziaczkowska, D. Opozda, t. 9, Lublin 2016, s. 19-38; taż, Znienawidzeni przez świat, ukochani przez Chrystusa: męczennicy w Peristephanon Prudencjusza, „Biografistyka Pedagogiczna”, 2 (2017) nr 1, s. 20-37.

39 E. Stępa, Hagiografia jako biografia ukazująca ponadczasowy wzorzec, „exemplum” do naśladowania, w: Badania biografii - źródła, metody, konteksty, red. R. Skrzyniarz, E. Krzewska, W. Zgłobicka-Gierut, t. 5, Lublin 2014, s. 97-116; A. Jabłońska, A. Kowalska-Pietrzak, Obraz duchowieństwa w świetle źródeł staropolskich, w: Przedmiot, źródła i metody badań $w$ biografii, red. R. Skrzyniarz, L. Dziaczkowska, D. Opozda, t. 9, Lublin 2016, s. 199215; R. Skrzyniarz, „Miechovia” Samuela Nakielskiego źródłem do biografii prepozytów miechowskich, w: tamże, s. 217-238. i nie trzymać się szlaków przetartych już przez poprzednich/wcześniejszych uczonych. Dla badacza ważne są wszelkiego rodzaju źródła, które stanowią materiał badaczy w konstruowanej biografii. Badacz robiący kwerendę archiwalną czy biblioteczną (tzw. źródłową) nie powinien dokonywać wstępnej selekcji źródeł, gdyż na tym etapie nie jest w stanie ocenić, które dokumenty będą mu przydatne, a które nie. Dopiero po zebraniu wszystkich źródeł może przeprowadzić wstępną selekcję materiału źródłowego, w trakcie której niektóre dokumenty odstawia, co wcale nie znaczy, że nie staną się mu one przydatne na przykład w przyszłości do napisania artykułu. Pomijając niektóre źródła, nie eliminuje ich definitywnie. One nie wejdą tylko 
$\mathrm{w}$ zakres omawianego tematu, ale mogę być przydatne do pogłębionych analiz innych zagadnień biograficznych osoby biografowanej.

Drugim typem dokumentów do badań biograficznych są:

2. Dokumenty niepisane - audiowizualne (obrazowo-dźwiękowe i elektroniczno-cyfrowe), wykorzystujące zdobycze techniki i nowoczesne media (obrazowe, dźwiękowe, elektroniczne). Zalicza się do nich:

- fotografie (zdjęcia, klisze, fotografie w zapisie elektronicznym) $)^{40}$;

- teksty prasowe, wywiady radiowe i telewizyjne;

- filmy dokumentalne ${ }^{41}$ i reportaże ${ }^{42}$, filmy biograficzne ${ }^{43}$, nagrania video;

- wywiad narracyjny, wywiad osobowy;

- dyskusje grupowe/wywiady z innymi;

- obserwacje etnograficzne ${ }^{44}$, ekspedycje terenowe ${ }^{45}$;

- blogi ${ }^{46}$, vlogi, portale społecznościowe, dzienniki internetowe, e-maile ${ }^{47}$.

Tego typu dokumenty zostały wytworzone współcześnie za pomocą najnowszych osiągnięć techniki i elektroniki, może z wyjątkiem fotografii i filmów, które są znane od XIX wieku. Dokumenty
40 M. Sikorska-Kowalska, Socjalista w kręgu rodzinnym. Fotografie $z$ archiwum domowego $w$ biografii Zygmunta Herynga, w: Przedmiot, źródła i metody badań w biografii, red. R. Skrzyniarz, L. Dziaczkowska, D. Opozda, t. 9, Lublin 2016, s. 353-366; J. Szymoniczek, Fotografia $w$ procesie identyfikacji poległych. Dokumentacja Deutsche Dienststelle i Niemieckiego Ludowego Zwiazku Opieki nad Grobami Wojennymi, w: tamże, s. 493-505.

41 J. Sosnowska, Współczesny filmowy dokument biograficzny w Polsce, w: Badania biografii - źródła, metody, konteksty, red. R. Skrzyniarz, E. Krzewska, W. Zgłobicka-Gierut, t. 5, Lublin 2014, s. 191-206.

42 J. Drozd, Bohaterowie Barbary Wachowicz schodza $z$ piedestału. Między reportażem a biografia, w: Biografia w literaturze i sztuce, red. R. Skrzyniarz, E. Krzewska, E. Kuryluk, t. 4, Lublin 2014, s. 99-110.

43 J. Gładysz, „Ja jedna zginę..." - biografia filmowa Danuty Siedzikówny ps. „Inka”, w: Wzory i wzorce osobowe $w$ biografistyce pedagogicznej, red. R. Skrzyniarz, M. Gajderowicz, T. Wach, t. 3, Lublin 2013, s. 251-26o; A. Kowalska-Pietrzak, Filmowe biografie bohaterów średniowiecza jako inspiracja do poszukiwań faktów i mitów, w: Badania biografii - źródła, metody, konteksty, red. R. Skrzyniarz, E. Krzewska, W. Zgłobicka-Gierut, t. 5, Lublin 2014, S. $177-190$.

44 B. Drozd, Obserwacja uczestniczaca $w$ badaniach jakościowych a poznanie kultury i języka danej społeczności, w: Biografia w edukacji etnoregionalnej, red. R. Skrzyniarz, E. Kuryluk, B. Drozd, t. 6, Lublin 2014, s. 55-64.

45 Tenże, Życie a pieśń tradycyjna. Kilka uwag młodego badacza z ekspedycji terenowych, w: tamże, s. 91-104.

46 E. M. Slaska, T. Fetzki, Na początku był blog: od prób literackich do pogłębionych badań nad nietypowymi biografiami pogranicza, „Biografistyka Pedagogiczna", 1 (2016) nr 1, s. 217-232.

47 P. Wawer, Biografia w społeczeństwie sieciowym dualizm „online" i „offline”?, w: Badania biografii - źródła, metody, konteksty, red. R. Skrzyniarz, E. Krzewska, W. Zgłobicka-Gierut, t. 5, Lublin 2014, s. 317-327; S. Krysa, Facebook jako biografia społeczności, w: tamże, s. 329-340; M. Smolarek, „Lubię to!" wspótczesny sposób kreowania siebie przez młodzież. Perspektywa socjopedagogiczna, w: tamże, s. 341-354. 
48 R. Tańczuk, Kolekcja jako przedmiot biograficzny, http://old.kultart.lnu.edu.ua/Visnyk_Cult-Arts/ 2007_07/Tanchuk.pdf, dostęp: 3.1.2018, nazywa je przedmiotami biograficznymi.

49 J. Szymoniczek, Przywracanie tożsamości poległych przez badanie źródeł zastanych - ekshumacje, dokumenty osobiste, przedmioty prywatne, w: Badania biografii - źródła, metody, konteksty, red. R. Skrzyniarz, E. Krzewska, W. Zgłobicka-Gierut, t. 5, Lublin 2014, s. 279-289.

50 D. Zalewska, Między życiem a literatura. Poszukiwanie śladów biografii pisarza $w$ wybranych tekstach Gustawa Herlinga-Grudzińskiego, w: Biografia w literaturze i sztuce, red. R. Skrzyniarz, E. Krzewska, E. Kuryluk, t. 4, Lublin 2014, s. 69-80; W. Zgłobicka-Gierut, Twórcza praca na emeryturze - Bronisława Betlej. Studium jednego przypadku, tamże, s. 177-191; E. M. Slaska, T. Fetzki, Eugenia Lublinerowa i jej dzieło; pogranicze biografii literackiej i monografii pedagogicznej, w: Przedmiot, źródła i metody badań $w$ biografii, red. R. Skrzyniarz, L. Dziaczkowska, D. Opozda, t. 9, Lublin 2016, s. 453-465.

51 J. Staroń, Feliks Araszkiewicz jako naukowiec i pedagog - na marginesie wykładów z Dydaktyki literatury polskiej, w: W stużbie nauki, wychowania i wartości. Szkice biograficzne o lubelskim środowisku naukowym, red. R. Skrzyniarz, M. Łobacz, B. Borowska, t. 8, Lublin 2015, s. 175-184.

52 J. Kostkiewicz, Krytyka warstwy wychowawczej totalitaryzmu komunistycznego lat dwudziestych $i$ trzydziestych $\mathrm{XX}$ wieku $w$ pismach Antoniego Szymańskiego, w: W stużbie nauki, wychowania i wartości. Szkice biograficzne o lubelskim środowisku naukowym, red. R. Skrzyniarz, M. Łobacz, B. Borowska, t. 8, Lublin 2015, s. 439-454.

53 U. M. Krzyżanowska, Twórczość autoportretowa jako źródło biografii. Przykład Fridy Kahlo, w: Przedmiot, źródła i metody badań $w$ biografii, red. R. Skrzyniarz, L. Dziaczkowska, D. Opozda, t. 9, Lublin 2016, s. 323-335.

54 D. Zimny, Olgi Pawluczuk życie muzyka, w: Biografia $w$ edukacji etnoregionalnej, red. R. Skrzyniarz, E. Kuryluk, B. Drozd, t. 6, Lublin 2014, s. 105-119. audiowizualne zostały zazwyczaj zapisane elektronicznie na różnego rodzaju dyskach pamięci i można je odtwarzać dopiero po uruchomieniu urządzenia elektronicznego. Przechowując taką dokumentację na różnego rodzaju elektronicznych nośnikach, możemy narazić się na ich utratę, gdyż powstają coraz to nowsze programy, a stare czasami przy konwersji tracą zawartość lub jej część, albo w ogóle uniemożliwiają jej odtworzenie. Ilość, a przede wszystkim typ pozostawionych śladów zwiększa się, a także zmieniają się proporcje ze względu na nowe technologie i zaprzestawanie starych (np. niegdyś epistolografia a obecnie maile i smsy).

3. Przedmioty związane $\mathrm{z}$ bohaterami biografii (przedmioty w badaniach biograficznych $\left.{ }^{48}\right)$ :

- przedmioty osobiste (pióro, obrączka, pierścionek, sygnet, portfel, grzebień, zapalniczka, filiżanka, kalendarze, różnego rodzaju gadżety i bibeloty, którymi otaczała się osoba biografowana, fotel, łóżko, wózek inwalidzki, ... $)^{49}$;

- wytwory twórczości artystycznej i naukowej (teksty literackie $^{50}$, wykłady ${ }^{51}$, publikacje $^{52}$, rysunki, obrazy ${ }^{53}$, zapisy nutowe, śpiew ${ }^{54}$, rękodzieło, 
spektakl teatralny ${ }^{55}$, teatr $\left.^{56}, \ldots\right)$;

- miejsce zamieszkania, pracy, szkoły (pałac, dom, mieszkanie, izba tradycji ${ }^{57}$, pracownia artystyczna ${ }^{58}$, tablica pamiątkowa po zburzonym budynku);

- miejsca pamięci: pomnik, mauzoleum, grobowiec, ...;

- komputer osobisty, telefon, smartfon, tablet ${ }^{59}, \ldots$;

- pieniądze (zawierają napisy, wyobrażenia osób, ich stroje, a także zwierzęta, rośliny i ornamenty).

Wskazane powyżej przedmioty nie wyczerpują listy obiektów, które mogą być przydatne w odtwarzaniu czy konstruowaniu biografii osoby lub osób biografowanych. Codziennie otaczamy się setkami przedmiotów, ale niektóre z nich są częściej przez nas użytkowane, a z wieloma jesteśmy związani czy to przez przyzwyczajenie, czy osobę od której otrzymaliśmy ten przedmiot.

Powyższe zestawienie daje obraz tego, gdzie możemy szukać poszczególnych dokumentów czy to źródłowych, audiowizualnych czy też przedmiotów związanych z osobą biografowaną. Należy się jeszcze zastanowić, jaką rolę odgrywają one w badaniach biograficznych.

\section{Rola i znaczenie dokumentów w badaniach biograficznych}

Niezmiernie ważną rolę w konstruowaniu lub rekonstruowaniu biografii (całościowej czy cząstkowej) człowieka, grupy osób czy instytucji wychowującej spełnia analiza treści dokumentów. Według Wincentego Okonia analiza (z grec. analysis - rozbiór) jest

55 K. Kułakowska, Improwizacja jako źródło badań biografii twórców postgrotowskiej tradycji teatralnej na przykładzie pracy Zofii Bartoszewicz i Erdmute Sobaszek nad spektaklem, w: Przedmiot, źródła i metody badań w biografii, red. R. Skrzyniarz, L. Dziaczkowska, D. Opozda, t. 9, Lublin 2016, s. 169-181.

56 K. Kułakowska, Biografie kobiet tworzacych polski teatr kontrkultury z perspektywy antropologii doświadczenia, w: Biografia w literaturze i sztuce, red. R. Skrzyniarz, E. Krzewska, E. Kuryluk, t. 4, Lublin 2014, s. 207-223.

57 R. Makarewicz, Regionalne izby tradycji - ich rola $w$ edukacji historyczno-kulturowej oraz znaczenie dla tworzenia biografii społeczności lokalnych. Przykład Multimedialnej Izby Tradycji w Garbowie, w: Biografia w edukacji etnoregionalnej, red. R. Skrzyniarz, E. Kuryluk, B. Drozd, t. 6, Lublin 2014, s. 43-54.

58 O. Rudenko, Pracownia artysty, jako źródło $w$ badaniach historyka sztuki, w: Przedmiot, źródła i metody badań $w$ biografii, red. R. Skrzyniarz, L. Dziaczkowska, D. Opozda, t. 9, Lublin 2016, s. 337-352.

59 Są one u współczesnych ludzi największą kopalnią informacji o ludziach współcześnie żyjących, poczynając od zdjęć, notatek, prac, pamiętników, zaś dla wielu artystów - obrazów, rysunków, plików muzycznych po pliki dokumentujące przeglądane strony. A swoją drogą ciekawe byłyby badania o komputerze osobistym jako źródle odkrywania biografii i ulotności przechowywanych tam informacji. 
to myślowe bądź fizyczne rozkładanie pewnej całości na części składowe w celach poznawczych (w celu poznania owych części i zachodzących między nimi związków) czy też praktycznych ${ }^{60}$. Łobocki uważa, że analiza „w szerokim znaczeniu tego słowa [...] dotyczy [...] zarówno wytworów pisanych, jak i niepisanych"61.

Przez analizę treści dokumentów rozumiemy badanie wszelkich wytworów (dokumentów) związanych z osobą biografowaną oraz opis i interpretację szeroko rozumianych tychże dokumentów. Aby analiza dokumentów była prawidłowa i rzetelna, konieczne jest sprawdzenie ich wiarygodności oraz prawdomówności ich twórcy lub twórców. Ustalenie wiarygodności twórcy pozwala badaczowi upewnić się, czy przekazane informacje są prawdziwe, czy zmanipulowane przez autora.

Przy badaniu autentyczności należy ustalić: 1) czas powstania i miejscu pochodzenia dokumentów; 2) jego oryginalność lub sfałszowanie (ustalenie autentyczności dokumentu daje badaczowi pogląd na warunki i okoliczności, w jakich on powstał); 3) adekwatność zawartych w nich treści z podejmowanym problemem badawczym ${ }^{62}$.

Analiza dokumentów ma za zadanie dotarcie do historii życia jednostki czy grupy osób i zachodzących w niej przemian psychicznych, społecznych, edukacyjnych, wychowawczych czy ekonomicznych. Pozwala na określenie norm, wzorów i wzorców osobowych jednostki lub grupy. Jej celem jest także wyeksponowanie działań dydaktycznych, wychowawczych, ogólnie ujmując pedagogicznych na innych ludzi lub na środowisko.

Same dokumenty pozornie nic nam nie „powiedzą”, natomiast analizując treść dokumentów możemy uzyskać wiele cennych informacji. Także forma dokumentu jest wiele mówiąca, np. jaki materiał pisarski, jaki charakter pisma, czy skrupulatnie zapisywany, czy byle jak, czy ktoś np. dbał o kalen-

6o W. Okoń, Nowy słownik pedagogiczny, Warszawa 2001.

61 M. Łobocki, Metody i techniki, s. 212.

62 Więcej na temat analizy dokumentów ich autentyczności oraz funkcji jako źródeł historycznych np.: M. Łobocki, Metody i techniki, s. 211-241; tenże, Wprowadzenie do metodologii badań pedagogicznych, Kraków 2010, s. 247-251; A. W. Maszke, Metodologiczne podstawy badań, 183-188; J. Topolski, Metodologia historii, Warszawa 1984, s. 322-237, 357-400. darz lub notatnik, czy jest on zabrudzony i pognieciony. Przede wszystkim i zdecydowanie gros informacji pochodzi z treści, dlatego tak ważna jest krytyka wewnętrzna. Często mam do czynienia z różnego rodzaju dokumentami i źródłami archiwalnymi i wiem, że oprócz treści tam zawartej otrzymam wiedzę o osobie 
biografowanej, której nikt mi nie przekaże. A mianowicie, z zebranych materiałów jestem w stanie wywnioskować jakiego typu była to osoba pod względem społecznym, ekonomicznym, religijnym, a nawet jakiego była temperamentu.

Analiza treści dokumentów może posłużyć do stworzenia, skomponowania czy odtworzenia:

- biografii indywidualnej/historycznej (historia życia od narodzin do śmierci);

- biografii zbiorowej (miejscowość, parafii, szkoły, wspólnoty, klasa, grupy osób o tych samych zainteresowaniach);

- biografii cząstkowej (fragmentu życia, np. edukacja, kariera; okres życia, np. starość);

- biografii miejsca pamięci (miejsc związanych z życiem i śmiercią osoby lub grupy osób);

- biografii edukacyjnej, wychowawczej, pedagogicznej.

Każda z tych wymienionych tu powyżej biografii winna opierać się na dokumentach. Nie wyobrażam sobie, żeby zajmować się biografią osoby lub grupy osób i marginalnie traktować lub pomijać dokumenty z nimi związane. W biografii indywidualnej czy historycznej staramy się wykorzystać wszystkie zebrane dokumenty, żebyśmy mieli jak najlepszy obraz osoby biografowanej. Podobnie jest w pozostałych typach biografii. Nawet pracując na wywiadzie musimy skonfrontować wypowiedzi ze stanem faktycznym, czyli sięgnąć do starych fotografii, dokumentów, wycinków prasowych, map, aby zweryfikować treści zawarte w wywiadzie, gdyż może się okazać, że osoba udzielająca wywiadu zapamiętała to inaczej niż było w rzeczywistości, a rolą badacza jest to odpowiednio skomentować.

Należy pamiętać, że biografia winna być umieszczona w konkretnym czasie i przestrzeni, które bezsprzecznie wywierają ogromny wpływ na nią ${ }^{63}$. Aby było to możliwe należy korzystać z różnego typu dokumentów, które pozwolą nam przybliżyć czas i przestrzeń oraz usystematyzują tok badań biograficznych.

Biografista musi być detektywem, pisarzem i kreatorem biografii pedagogicznej. Jako detektyw zajmuje się poszukiwaniem różnego rodzaju dokumentów i źródeł do biografii.

63 G. Szuster, Biografia przez epoki. Wincenty Danek (1907-1976). Trajektoria biograficzna i podstawa źródłowa, w: Przedmiot, źródła i metody badań $w$ biografii, red. R. Skrzyniarz, L. Dziaczkowska, D. Opozda, t. 9, Lublin 2016, s. 133-152; J. Bartkowski, Problemy metodologiczne $w$ badaniach karier działaczy lokalnych, w: tamże, s. 415-434. 
Czyta, ogląda, analizuje i poddaje w wątpliwość zgromadzone źródła. Poddaje je wszechstronnej krytyce, zestawia różnego rodzaju źródła, które są wątpliwe. Docieka, co jest przyczyną odmiennych treści w zebranych materiałach badawczych. Kiedy już wyjaśni wszelkie wątpliwości, poukłada źródła i zgromadzone materiały, musi stać się pisarzem, aby dokonać rekonstrukcji biografii w oparciu o zebrane dokumenty. Każda rekonstrukcja biografii będzie skażona sposobem myślenia, analizowania, zaangażowania badacza w biografię osoby biografowanej ${ }^{64}$. Można by nawet rzec, że biografista jest kreatorem nowej biografii ${ }^{65}$. Załóżmy, że trzy osoby pracują na tych samych źródłach nad biografią jednej osoby. Jestem święcie przekonany, że powstaną trzy różne biografie, gdyż każda z osób zwróci uwagę na coś innego, podkreśli inne walony, w inny sposób przeanalizuje zebrane treści źródłowe. W konstruowaniu czy rekonstruowaniu biografii należy pamiętać o etycznej stronie podejścia do biografii osoby biografowanej. Badacz bez wiedzy i zgody osoby biografowanej lub jej rodziny i bliskich nie powinien upubliczniać informacji, które mogą być krępujące lub skandaliczne ${ }^{66}$. Biografistyka dotyczy człowieka, jest przekazywana dzięki pośrednictwu człowieka i ostateczny obraz też jest rekonstruowany przez człowieka. Każdy człowiek, w większym lub mniejszym stopniu, świadomie lub nieświadomie jest subiektywny choćby ze względu na swoje poglądy, które każdy jakieś posiada, ze względu na swoje cele, sympatie i antypatie. Ponadto stosunki międzyludzkie, odbiór i ocena innych, a zwłaszcza siebie, jest nacechowany emocjami, wobec których bardzo trudno jest zastosować całkowity obiektywizm. Istotna może być

64 A. Całek, Narrator biografii naukowej: między referencyjnością a fikcją, w: Przedmiot, źródła i metody badań $w$ biografii, red. R. Skrzyniarz, L. Dziaczkowska, D. Opozda, t. 9, Lublin 2016, s. 39-58.

65 G. Kubski, Narracja o życiu Błogosławionej Poznańskiej Piątki-jak relikwiarz w przestrzeni kultycznej, w: Przedmiot, źródła i metody badań w biografii, red. R. Skrzyniarz, L. Dziaczkowska, D. Opozda, t. 9, Lublin 2016, s. 61-77.

66 K. Chrzęszczyk, Strategie Agaty Tuszyńskiej w „spotkaniu" $z$ Wierą Gran, czyli o etyczności biografii, w: Przedmiot, źródła i metody badań $w$ biografii, red. R. Skrzyniarz, L. Dziaczkowska, D. Opozda, t. 9, Lublin 2016, s. 467-482. także chęć wykazania z góry przyjętego założenia lub celu.

Obok pryzmatu człowieka tworzącego dokumenty i tego, który je analizuje, dodatkowymi aspektami, o których należy pamiętać, jest także specyfika pamięci oraz odległość czasowa od opisywanych wydarzeń. Nigdy nie należy oceniać minionych wydarzeń czy sytuacji z perspektywy obecnej rzeczywistości badacza biografii, należy poznać historię i rzeczywistość okresu badanego. 
Tworząc biografię osoby, grupy osób czy środowiska jesteśmy odpowiedzialni za rzetelny i naukowy przekaz. Nie wszystko da się przekazać tak, jak byśmy sobie wyobrażali lub jakby widziała lub chciała to osoba biografowana. Zatem spada na biografistę ogromna odpowiedzialność za przekaz treści i wartości związanych z tym o kim piszemy. Jako ciekawostkę można podać, że powstały biografie Boga Ojca, Syna Bożego i Ducha Świętego oparte na Biblii, dokumentach Kościoła oraz doświadczeniu i przemyśleniach autorki. Nie są to typowe biografie, bo też ich bohaterzy są nietuzinkowi i trudno jest napisać ich biografię taką jaką mają osoby żyjące w konkretnym czasie i przestrzeni ${ }^{67}$.

Biografistyka pedagogiczna należy do tych badań, które łatwo mogą wejść na meandry braku obiektywizmu, dlatego wymagają zwiększonego poczucia odpowiedzialności i etyki, a przede wszystkim odpowiedniego warsztatu metodologicznego, dlatego tak istotne jest ścisłe określenie tych podstaw.

67 M. Miduch, Biografia Ducha Świętego, Kraków 2015; taż, Biografia Boga Ojca, Kraków 2016; taż, Biografia Syna Bożego, Kraków 2017. 
